\title{
Identifying language learning gaps of ESL students at intermediate level in Pakistani colleges
}

\author{
Muhammad Arfan Lodhi \\ Higher Education Department Collegiate Wing, Government of the Punjab
}

Amber Akash

National College of Business Administration \& Economics

(Text received December 29 2018; accepted March 21 2019; final version March 22 2019)

DOI: https://doi.org/10.5565/rev/jt13.783

\begin{abstract}
The study attempted to evaluate the existing language proficiency level of $12^{\text {th }}$ grade students and compared the results with the relevant learning standards fixed by the CEFR for these intermediate level language users. The data was collected and analyzed quantitatively from a random sample of 200 students from government and private colleges in Pakistan. A language proficiency test, checklist and questionnaire were administered as data collection instruments. The findings of the study reflected huge learning gaps between the acquired and desired proficiency levels of language learners. Data shows that the majority of the students were found at initial level of basic users for all seven language learning skills i.e. reading, writing, listening, speaking, vocabulary, grammar and sociolinguistic appropriateness. It is highly recommended to adopt appropriate and effective instructional plans to increase the language proficiency level of students up to the required standards.
\end{abstract}

Key Words: language learning gaps, CEFR standards, English proficiency, ESL pedagogy

Resum: L'estudi intenta avaluar el nivell de competència lingüística existent dels estudiants de dotzè grau i compara els resultats amb els estàndards d'aprenentatge rellevants establerts pel CEFR per a aquests usuaris de nivell intermedi. Les dades es van recollir i analitzar quantitativament a partir d'una mostra aleatòria de 200 estudiants de les escoles públiques i privades de Pakistan. Es van administrar una prova de competència lingüística, una llista de control i un qüestionari com a instruments de recollida de dades. Les conclusions de l'estudi reflecteixen grans llacunes d'aprenentatge entre els nivells de competència adquirits i desitjats dels aprenents de llengües. Les dades mostren que la majoria dels estudiants es troben al nivell inicial d'usuaris bàsics per a les set competències d'aprenentatge d'idiomes, és a dir, escriure, escoltar, parlar, vocabulari, gramàtica i adequació sociolingüística. Es recomana adoptar plans d'ensenyament adequats i efectius per augmentar el nivell de competència lingüística dels estudiants per aconseguir els estàndards requerits.

Paraules clau: buits en l'aprenentatge de llengües, estàndards CEFR, domini de l'anglès, pedagogia ESL (anglès llengua segona)

Resumen: El estudio intenta evaluar el nivel de competencia lingüística existente de los estudiantes de $12^{\circ}$ grado y compara los resultados con los estándares de aprendizaje relevantes establecidos por el CEFR para estos usuarios de idiomas de 
nivel intermedio. Los datos se recopilaron y analizaron cuantitativamente a partir de una muestra aleatoria de 200 estudiantes de colegios públicos y privados en Pakistán. Se administraron una prueba de dominio del idioma, una lista de verificación y un cuestionario como instrumentos de recolección de datos. Los resultados del estudio reflejan enormes brechas de aprendizaje entre los niveles de competencia adquiridos y deseados de los estudiantes de idiomas. Los datos muestran que la mayoría de los estudiantes se encuentran en el nivel inicial de usuarios básicos para las siete habilidades de aprendizaje de idiomas, es decir, lectura, escritura, comprensión auditiva, expresión oral, vocabulario, gramática y adecuación sociolingüística. Es altamente recomendable adoptar planes de instrucción apropiados y efectivos para aumentar el nivel de dominio del idioma de los estudiantes hasta los estándares requeridos.

Palabras clave: brechas en el aprendizaje de idiomas, estándares CEFR, dominio del inglés, pedagogía de ESL (inglés lengua segunda)

\section{Introduction}

This study investigates the factors that influence Grade 12 learners' performance in ESL in one poor performing school and one better performing school in Pakistan. The study further seeks to find out what is done differently in the two schools which contributes to the identified learners' performance. It is noted that ESL students face difficulties in some aspects of listening comprehension, communicative abilities in asking and responding to questions, using fluent English in class participation and producing academic English texts.

\section{Learning gaps}

Learning gaps in language affect students' abilities to access core textbooks and communicate and write effectively within the various subject areas. Our experience suggests that these language gaps catch up to many students in the context of our research - Pakistan as they enter high school and feel overwhelmed by the challenges of increasing academic standards and more difficult vocabulary. These language gaps can have devastating effects on students (Hirsch, 2007). Children who come to school speaking a different language or lack the academic language of school struggle to meet curricular requirements, and they often feel overwhelmed in the classroom. Examining the root causes of students' difficulties in school, research suggests that a lack of academic language may be a significant factor that contributes to language gaps, as well as related literacy gaps, and, ultimately, overall school achievement gaps. Francis et al. (2006, p. 7) speak of the issue in this way: "Mastery of academic language is arguably the single most important determinant of academic success for 
individual students". Students' future success, therefore, depends on our helping them learn academic language.

\section{Language Policy in Pakistan}

In Pakistan, English is both a colonial and post-colonial legacy which resonates well with global communication regimes. The English language was a medium of communication in the country in the $19^{\text {th }}$ century between natives and settlers. It became a medium of instruction in schools in the $21^{\text {st }}$ century by gaining the status of official language of Pakistan. Whilst the 2009 National Education Policy (NEP) underscores that English "is important for competition in a globalized world order", it also emphasizes that "The challenge is that a child is able to carry forward their cultural assets and, at the same time, be able to compete nationally and internationally" (para 21). In Punjab the political leadership announced a radical policy change making English the official medium of instruction in all government schools in 2009-2010, so that English competencies can be assured for not just English as a subject, but also mathematics, science, IT and social studies. This sudden decree for all public sector schools met with a great deal of criticism but has persisted over time. It is supported by the continuous professional development (CPD) framework of the Directorate of Staff Development (DSD), the apex in-service teacher-training institution of the Punjab Schools Department. Teachers' professional development is done with the help of decentralized facilitations across each district with master trainers (MTs) at the cluster training support centers (CTSCs) and district teacher educators (DTEs) at school-based district teacher support centers (DTSCs) to address in-service and school-based needs in defined catchment areas. The focus of DSD is to train and support teachers and head teachers progressively across the system, in primary, middle and secondary schools. To the best of our knowledge, there has so far not been any evaluation of the consequences of this significant policy change in the province.

The primary objective of the National Education Policy (2009) in the last few years has been to improve the level and quality of education in Pakistan. The government vision is to expand primary education and this measure can be used to assess whether government schools have increased their coverage, by increasing enrolments faster than the growth in population, especially at the primary level because that level forms the core of the literate population. Literacy and primary school enrolment rates in Pakistan have shown improvement during the last five years, but they are still lagging behind other countries in the 
region. Scarcity of resources and inadequate provision of facilities and training are the primary obstacles in imparting and expanding education. The present government's strategy for the sector includes improving the functioning and utilization of existing schools, improving the quality of education, increasing enrolment, improving access to education and expanding the primary education system. Under the 18th constitutional amendment, control and management of the education sector has been devolved to the provinces. They are now responsible for the key areas of the education sector - i.e. curriculum and syllabus, centers of excellence, standards of education up to intermediate level (Grade 12) and Islamic education. Planning and policy, and standards of education beyond Grade 12 are covered under the Federal Legislative List as mentioned in the NEP (2009). All the provinces have shown their commitment to the 2009 National Education Policy. However, the acquired level of competencies is far behind the desired level of competencies.

\section{Research design}

The study adopted a descriptive framework and followed a mixed method approach. Data was collected through both quantitative and qualitative methods. The study aims to identify language learning gaps of students at intermediate level (Grade 12).

\section{Population and sampling}

The population of the study comprised the intermediate level students of Bahawalpur district, Pakistan. The sample was taken from four different colleges in the district. The colleges were selected from both private and government institutions. Fifty students were selected from each of the four colleges and the total sample size reached 200 students. A two-stage sampling technique was employed to determine the sample of the study. The colleges were selected through using the convenience sampling technique. According to Taherdoost (2016) this sampling strategy is employed to select participants of the study on the basis of researcher's convenience. However, students selected from these colleges were selected by using the simple random sampling technique. The random sampling technique is the one most commonly used in quantitative research (Taherdoost, 2016). Participants were learning English as their second language in ESL classes. They had different first languages, including Urdu, Punjabi and Saraiki languages, as their mother tongue. 


\section{Data collection tools}

Data was collected by using three different tools. The tools selected were a test, checklist and questionnaire.

A test was used to measure existing English proficiency skills of the participants of this study. The test was adopted from the CEFR project report that was used to assess linguistic competence and learning gaps of English language learners in eight different countries in 2002 (Source: https://www.eva.dk/projekter/2002/evaluering-af-faget-engelsk-igrundskolen assessment ofenglish.pdf). The test items were taken from already developed and used inventories and then further modified according to the requirements of the study. The test was used to assess the vocabulary skills, reading comprehension and writing skills of the participants. The total number of points for the test was 50 with five different questions. The division of questions and related skills are listed in Table 1, below:

Table 1. Description of test

\begin{tabular}{|l|c|c|}
\hline \multicolumn{1}{|c|}{ Question } & Skill Measured & Marks \\
\hline Question 1 & Vocabulary Skills & 05 \\
\hline Question 2 & Vocabulary Skills & 12 \\
\hline Question 3 & Reading Skills & 16 \\
\hline Question 4 & Reading Skills & 15 \\
\hline Question 5 & Writing Skills & 50 \\
\hline Total & & 502 \\
\hline
\end{tabular}

A checklist was used as another data collection tool. It was distributed among the participants after collecting the data from the test. Students were asked to respond based upon their experiences and knowledge regarding English proficiency skills. The checklist comprised 14 closed-ended items. The responses were demanded on a 4-point scale with the different options (see Appendix 1): "very easy", "rather easy", "rather difficult", "very difficult".

Finally, a questionnaire was used. The items and assessment criteria of the questionnaire were adopted from the CEFR, which is standard tool to assess language proficiency skills and measure learning gaps. The CEFR has devised different standards for different level learners. Students were assessed on seven different skills with 42 different closed-ended items (see Appendix 2). The responses were demanded on 3-point likert scale: "always true of me", "somewhat true of me", and "never true of me". 
Researchers administered the data collection tools after ensuring their validity and reliability during a pilot testing phase. The items on the questionnaire and checklist were translated into the Urdu language to provide more comprehensible input to the participants. However, their responses were collected on the English version of the questionnaire and checklist.

\section{Analysis of the data obtained from the ESL proficiency test}

Table 2 shows the statistical representation of the data obtained from the language proficiency test in vocabulary skills. Their overall score on the vocabulary test was $45.43 \%$, with female students scoring higher $(51.4 \%)$ than male students $(39.3 \%)$. Vocabulary grades of government school students were lower than private school students. The average vocabulary score of male students was 2.2 and of female students was 3.4, with a cumulative mean of 2.80 in government institutions. However, in private institutions the vocabulary score of male students was 3.3 and female students' was 3.8, with a cumulative mean value of 3.55. Comparatively, female students from private institutions scored highest with a mean score of 3.8 and a percentage value of $54.2 \%$ on the vocabulary test. On the other hand, male students from government institutions scored lowest on the vocabulary test as their mean score was 2.2, with a percentage level of $31.4 \%$. The data indicates that students performed average on the vocabulary proficiency test as their overall proficiency level was satisfactory, with a mean score of 3.18. The data shown in Table 2, and also in Table 3 (below) demonstrates that female learners achieved significantly higher score than male learners.

Table 2. Comparison of test scores in vocabulary skills

\begin{tabular}{|l|c|c|c|}
\hline \multicolumn{1}{|c|}{ Vocabulary Skills (07 Marks) } & Male Scores & Female score & Total Scores \\
\hline Govt. Students (Mean Score) & 2.2 & 3.4 & 2.80 \\
\hline Govt. Students (Percentage) & $31.4 \%$ & $48.6 \%$ & $40 \%$ \\
\hline Private Students (Mean Score) & 3.3 & 3.8 & 3.55 \\
\hline Private Students (Percentage) & $47.1 \%$ & $54.2 \%$ & $50.65 \%$ \\
\hline Total Mean Score (Vocabulary) & 2.75 & 3.6 & 3.18 \\
\hline Total Percentage (Vocabulary) & $39.3 \%$ & $51.4 \%$ & $45.43 \%$ \\
\hline
\end{tabular}

Students' reading proficiency skills were measured through two questions in the language proficiency test. The reading skills part of the text covered 28 marks in total. The data shown in Table 3 demonstrates the comparison of students' test grades in the reading 
proficiency test. The data shows that male learners in government institutions obtained the lowest grades with an average mean score of 9.7 and a percentage value of $34.6 \%$. On the other hand, female learners in private institutions scored highest with a mean value of 14.5 and a percentage value of 51.8\%. Female students in government institutions scored $37.2 \%$ marks while male learners in private institutions obtained $42.1 \%$ marks on average. The data shows that students did not attain satisfactory grades in the reading proficiency test as their overall mean score was 11.6 with an average percentage of $41.5 \%$ in total. The data also shows that female students performed significantly better than male students. The marks in reading test were found lower than average vocabulary scores of the students.

Table 3. Comparison of test scores in reading skills

\begin{tabular}{|l|c|c|c|}
\hline \multicolumn{1}{|c|}{ Reading Skills (28 Marks) } & Male Scores & Female score & Total Scores \\
\hline Govt. Students (Mean Score) & 9.7 & 10.4 & 10.05 \\
\hline Govt. Students (Percentage) & $34.6 \%$ & $37.2 \%$ & $35.9 \%$ \\
\hline Private Students (Mean Score) & 11.8 & 14.5 & 13.15 \\
\hline Private Students (Percentage) & $42.1 \%$ & $51.8 \%$ & $47 \%$ \\
\hline Total Mean Score (Reading Skills) & 10.75 & 12.45 & 11.6 \\
\hline Total Percentage (Reading Skills) & $38.4 \%$ & $44.5 \%$ & $41.5 \%$ \\
\hline
\end{tabular}

The writing proficiency part of the test consisted of 15 marks. Participants showed average performance in the writing proficiency test. Table 4 represents test scores in the writing skills of ESL students. Male students from government institutions performed very poorly as their mean score was just 3.4, with a minimum percentage value of $22.7 \%$. In addition to the former description, female students from government institutions obtained slightly higher grades with a mean value of 5.6 and a percentage rate of $37.3 \%$. The overall result of government sector students was less satisfactory, with a mean score of 4.5 and percentage of just $30 \%$. On the contrary, private sector students performed much better than their government sector counter parts in the writing proficiency test. The average mean of private sector male students was 8.4 and female learners' was 10.6 , with $56 \%$ and $70.7 \%$ respectively. The total marks of private sector students were more than double the government sector students', with an overall percentage of $63.3 \%$. The data shows that female students from private institutions performed highest whereas male students from government institutions scored lowest. The total mean score in writing skills of male students was 5.9 with a percentage value of $39.4 \%$. Writing grades of female learners from both 
sectors was higher than male students, with a mean score of 8.1 and a percentage of $54 \%$. The data also shows that the writing proficiency level of students overall was found satisfactory with a percentage of $46.7 \%$.

Table 4. Comparison of test scores in writing skills

\begin{tabular}{|l|c|c|c|}
\hline \multicolumn{1}{|c|}{ Writing Skills (15 Marks) } & Male Scores & Female score & Total Scores \\
\hline Govt. Students (Mean Score) & 3.4 & 5.6 & 4.5 \\
\hline Govt. Students (Percentage) & $22.7 \%$ & $37.3 \%$ & $30 \%$ \\
\hline Private Students (Mean Score) & 8.4 & 10.6 & 9.5 \\
\hline Private Students (Percentage) & $56 \%$ & $70.7 \%$ & $63.3 \%$ \\
\hline Total Mean Score (Writing Skills) & 5.9 & 8.1 & 7 \\
\hline Total Percentage (Writing Skills) & $39.4 \%$ & $54 \%$ & $46.7 \%$ \\
\hline
\end{tabular}

Table 5 represents the overall performance of ESL students on the language proficiency test. Out of the total 50 marks of the test, male students from both private and government institutions obtained an average mean of only 19.4, whereas female students' average score was 24.15 , with a cumulative mean of 21.78 . The data shows that students' overall performance in the test was poor as the overall mean score of the total sample was 21.78 , with a percentage of $43.6 \%$. However, when results are discussed in isolation, female private sector students obtained satisfactory grades with significant marks at $57.8 \%$. The lowest performance was observed among male students from government institutions whose mean score was 15.3 , with a percentage level of $30.6 \%$. The data shows that male and female students from government institutions performed lower than male and female learners from the private sector. Overall, the existing language proficiency level of selected students was found below standard in relation to the CEFR learning standards at intermediate level (Grade 12).

Table 5. Comparison of overall test scores

\begin{tabular}{|l|c|c|c|}
\hline \multicolumn{1}{|c|}{$\begin{array}{c}\text { Overall Test scores } \\
(50 \text { Marks) }\end{array}$} & Male Scores & Female score & Total Scores \\
\hline Govt. Students (Mean Score) & 15.3 & 19.4 & 17.35 \\
\hline Govt. Students (Percentage) & $30.6 \%$ & $38.8 \%$ & $34.7 \%$ \\
\hline
\end{tabular}




\begin{tabular}{|l|c|c|c|}
\hline Private Students (Mean Score) & 23.5 & 28.9 & 26.2 \\
\hline Private Students (Percentage) & $47 \%$ & $57.8 \%$ & $52.4 \%$ \\
\hline Total Mean Score (Overall Test) & 19.4 & 24.15 & 21.78 \\
\hline Total Percentage (Overall Test) & $38.8 \%$ & $48.3 \%$ & $43.6 \%$ \\
\hline
\end{tabular}

\section{Analysis of the data obtained from the questionnaire}

After obtaining the data about the existing ESL proficiency skills through the test and checklist, students were given a questionnaire to record their opinions in the light of their knowledge, experience or observations. The questionnaire was developed to determine the learning standards, learning gaps and existing proficiency level of ESL students at intermediate level. As stated earlier, the questionnaire was developed from the CEFR framework that provides an accurate and comprehensive layout for assessing language proficiency levels and determining gaps. The data obtained from this questionnaire was calculated as percentages for three main proficiency levels (A, B and C) with two sub-levels of each proficiency standards (A1, A2, etc.). The calculated percentage determined whether learners fall in the range of basic users of English, independent users or proficient users.

Learning standards were measured for seven different English proficiency skills and they have been analyzed independently one by one. The data shown in Table 6 represents participants' learning standards in reading proficiency skills. The data shows that $51 \%$ of students claimed that they can always understand short and simple messages on text and postcards etc.; however $21 \%$ stated they sometimes do so, and $22 \%$ disagreed that they can understand simple messages. Similarly $60 \%$ affirmed that they can understand everyday signs written in English on public places, railway boards, traffic signs and restaurants by stating this as always true and sometimes true of them. The data also shows that the majority of respondents claimed not to understand higher and complex level of texts and signs, including long and short literary and non-literary texts. The majority of the students rated themselves as basic users of the English language in reading skills as they claimed not to understand and read texts at advanced levels. The graphical representation in Table 6 shows that students responded "never true of me" most often in response to the statements in the B and C columns. This suggests that students considered their reading proficiency level as basic users of language in this skill area. Even at basic level, 22\% and 40\% students denied that they have developed their reading skills at A1 and A2 level respectively, even though, being at 
intermediate level (Grade 12), it was expected from them to have at least level B proficiency in reading skills.

Table 6. Learning standards in reading skills

\begin{tabular}{|c|c|c|c|}
\hline Level & Always true of me & Somewhat true of me & Never true of me \\
\hline A1 & 51 & 27 & 22 \\
\hline A2 & 38 & 22 & 40 \\
\hline B1 & 12 & 23 & 65 \\
\hline B2 & 9 & 24 & 67 \\
\hline C1 & 19 & 36 & 45 \\
\hline C2 & 8 & 19 & 73 \\
\hline
\end{tabular}

The data shown in Table 7 represents students' learning standard levels in English writing skills. The data shows that $72 \%$ of students claimed that it is always true for them that they can write simple, isolated phrases and sentences, $15 \%$ reported this as somewhat true for them, whereas $13 \%$ students responded that this was never true for them. It is further evident from Table 7 that $84 \%$ of students can write simple and short messages on matters related to everyday life. Furthermore, $26 \%$ of students responded it was always true that they can describe basic details about any kind of unpredictable occurrences, $47 \%$ stated this was somewhat true for them, while $27 \%$ stated this was never true for them. The majority of the respondents denied being able to speculate in English about causes, consequences, hypothetical situations, or develop arguments systematically. The data shows that $14 \%$ of students responded as always true, $21 \%$ as somewhat true and $65 \%$ as never true for them the statement that they can produce clear, smoothly flowing, complex reports, articles or essays that present a case, or give critical appreciation of proposals or literary works. The data also shows that the majority of the learners claimed not to achieve the $\mathrm{C} 1$ and $\mathrm{C} 2$ proficiency levels in writing skills. As compared to learning standards in reading skills, students were found comparatively more proficient in the learning standards for writing skills; however they were basic language users in English writing skills, as they were also in reading skills. There were only some students who were independent and proficient users of English in terms of their writing skills. 
Table 7. Learning standards in writing skills

\begin{tabular}{|c|c|c|c|}
\hline Level & Always true of me & Somewhat true of me & Never true of me \\
\hline A1 & 72 & 15 & 13 \\
\hline A2 & 68 & 26 & 6 \\
\hline B1 & 26 & 47 & 27 \\
\hline B2 & 21 & 34 & 44 \\
\hline C1 & 19 & 17 & 64 \\
\hline C2 & 14 & 21 & 65 \\
\hline
\end{tabular}

The data described in Table 8 displays students' responses regarding listening proficiency levels. Students gave a variety of opinions about different statements. It was found that the majority of the students (52\%) can always understand everyday expressions clearly during listening, $29 \%$ can sometimes, while $19 \%$ negated the statement stating that it was never true for them. $38 \%$ of the students claimed that they can generally understand familiar matters, $47 \%$ can sometimes and $15 \%$ students negated this statement as never true for them. The data shows that the majority of the learners were found to be independent users in terms of their listening proficiency skills. However, only small percentage of learners was found to be proficient in terms of English listening skills.

Table 8. Learning standards in listening skills

\begin{tabular}{|c|c|c|c|}
\hline Level & Always true of me & Somewhat true of me & Never true of me \\
\hline A1 & 52 & 29 & 19 \\
\hline A2 & 38 & 47 & 15 \\
\hline B1 & 28 & 37 & 35 \\
\hline B2 & 26 & 30 & 44 \\
\hline C1 & 8 & 13 & 79 \\
\hline C2 & 10 & 13 & 77 \\
\hline
\end{tabular}

Table 9 shows the data regarding learning standards in speaking skills. The majority of the students were found to be basic users of the English language in this domain; though slightly less than half of the sample even denied being able to speak English at a basic level. Data shows that there was huge gap between the aimed and attained oral proficiency levels. Less than $10 \%$ of the participants rated themselves as achieving the standards of independent users and proficient users in the speaking domain. Furthermore, a majority of the learners 
claimed not to attain basic level skills in speaking. This skill was found to be least developed among intermediate level (Grade 12) students as compared to the other three skills i.e. reading, writing and listening.

Table 9. Learning standards in speaking skills

\begin{tabular}{|c|c|c|c|}
\hline Level & Always true of me & Somewhat true of me & Never true of me \\
\hline A1 & 34 & 21 & 45 \\
\hline A2 & 17 & 09 & 74 \\
\hline B1 & 09 & 14 & 77 \\
\hline B2 & 8 & 10 & 82 \\
\hline C1 & 14 & 11 & 75 \\
\hline C2 & 9 & 8 & 83 \\
\hline
\end{tabular}

Table 10 shows students' data regarding the learning standards in vocabulary skills. The data shows that $34 \%$ of students have developed their own vocabulary banks to explain concrete situations, $48 \%$ of students stated that this was somewhat true, while $18 \%$ rated this as never true of them. However, it is also evident from the data given in Table 10 that $58 \%$ of respondents negated having enough vocabulary to fulfill their basic communicative needs. The remaining $27 \%$ and $17 \%$ of respondents stated this was "always true of me" and "somewhat true of me" respectively. Similarly, a wide majority of the participants did not feel represented in the statements related to $\mathrm{B}$ and $\mathrm{C}$ level proficiency skills. The data signifies that the majority of the participants were only the basic users of English in the vocabulary proficiency domain.

Table 10. Learning standards in vocabulary skills

\begin{tabular}{|c|c|c|c|}
\hline Level & Always true of me & Somewhat true of me & Never true of me \\
\hline A1 & 34 & 48 & 18 \\
\hline A2 & 25 & 17 & 58 \\
\hline B1 & 21 & 10 & 69 \\
\hline B2 & 20 & 14 & 66 \\
\hline C1 & 9 & 7 & 84 \\
\hline C2 & 8 & 11 & 81 \\
\hline
\end{tabular}


Table 11 shows data related to learning standards in grammar skills. The data shows that the majority of students ranked themselves as basic users in grammatical competencies. $31 \%$ students responded "always true of me" and $38 \%$ responded "somewhat true of me" that they have limited control of simple grammatical structures and syntactical orders in a learnt repertoire; though $31 \%$ negated the statement. $77 \%$ of participants affirmed that they make systematic errors by mixing up tenses and making agreement mistakes. $18 \%$ of students affirmed that they can communicate with reasonable accuracy in familiar contexts, while $16 \%$ responded that they have good control of grammatical usage. Only a few participants stated that they have attained a higher level of grammatical accuracy, but the majority of the respondents expressed their difficulties in terms of grammatical accuracy and competencies. Here too, the large majority of the participants were proven to be basic users of grammar. Even at the basic level, about $25 \%$ of the students negated the statements for A1 and A2. The data obtained from students expressed a huge gap between the required learning standards and existing proficiency skills in the domain of grammatical competence.

Table 11. Learning standards in grammar skills

\begin{tabular}{|c|c|c|c|}
\hline Level & Always true of me & Somewhat true of me & Never true of me \\
\hline A1 & 31 & 38 & 31 \\
\hline A2 & 30 & 47 & 23 \\
\hline B1 & 18 & 40 & 42 \\
\hline B2 & 16 & 31 & 53 \\
\hline C1 & 9 & 14 & 77 \\
\hline C2 & 8 & 11 & 81 \\
\hline
\end{tabular}

The CEFR learning standards include sociolinguistic appropriateness as an important factor in the language learning standards. Table 12 shows students' levels in terms of sociolinguistic appropriateness. The data shows that only $8 \%$ of participants always establish basic social contacts by using the simplest everyday polite forms of greeting, etc.; $14 \%$ stated this was somewhat true for them, while $78 \%$ expressed that the statement was never true for them. Similarly, $18 \%$ of participants can always somewhat handle short social exchanges, while $82 \%$ can never handle language related to apologies, invitations or suggestions, etc. A slightly higher number of participants (29\%) affirmed B2 level competency in terms of being able to participate well in group discussions. The reason for this competency is their active engagement in classroom group discussions. Otherwise, on the whole, a large majority of 
students denied attaining any high standards in terms of sociolinguistic appropriateness. The representation in Table 12 shows the highest number of "never true of me" responses as compared to the different language skills discussed earlier. Despite the fact that the number of independent and proficient users in this area was much fewer, even the percentage of basic users in this area was low.

Table 12. Learning standards in sociolinguistic appropriateness

\begin{tabular}{|c|c|c|c|}
\hline Level & Always true of me & Somewhat true of me & Never true of me \\
\hline A1 & 8 & 14 & 78 \\
\hline A2 & 11 & 7 & 82 \\
\hline B1 & 9 & 10 & 81 \\
\hline B2 & 13 & 16 & 71 \\
\hline C1 & 7 & 8 & 85 \\
\hline C2 & 8 & 9 & 83 \\
\hline
\end{tabular}

\section{Overall proficiency level of learners}

The data shown in Table 13 demonstrates the overall proficiency level of ESL learners at the intermediate level (Grade 12). The table shows wide-scale language and literacy gaps between the required curricular standards and existing linguistic competencies of ESL learners at the intermediate level. The data suggests that male students in government schools had initial levels of competencies required for basic users for all seven language learning skills i.e. reading, writing, listening, speaking, vocabulary, grammar and sociolinguistic appropriateness. Similarly, female learners from government institutions were also found to be at the same level, except in writing skills where they were found to be at the upper level of basic users. Male learners from private institutions were also found to be basic users of English, except for vocabulary skills where they had an A2 level. On the other hand, female students from private institutions were overall found to be basic users, but had upper basic level (A2) skills for writing skills were independent users (B1) for vocabulary skills. Hence, the data shows that there existed a huge learning gap between the required curricular proficiency levels and students' existing levels in the English language. According to the curriculum, they should be independent and proficient users for the different language skills. However the findings revealed that the majority of them were at the most basic level of proficiency for the different language skills. The results obtained from the test and the 
checklist also showed similar kinds of results. Female learners from government institutions were found to be more proficient than other students from government and private institutions.

Table 13. Overall proficiency level of the learners at intermediate level (grade 12)

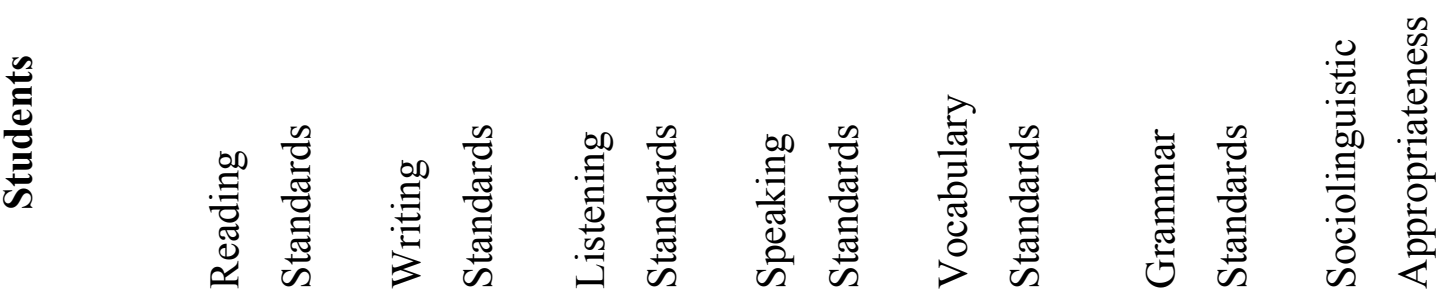

$\begin{array}{llllllll}\text { Govt. } & \text { A1 } & \text { A1 } & \text { A1 } & \text { A1 } & \text { A1 } & \text { A1 } & \text { A1 } \\ \text { Male } & & & & & & & \\ \text { Govt. }\end{array}$

$\begin{array}{llllllll}\text { Govt. } & \text { A1 } & \text { A2 } & \text { A1 } & \text { A1 } & \text { A1 } & \text { A1 } & \text { A1 }\end{array}$

Female

\begin{tabular}{cccccccc}
$\begin{array}{c}\text { Private } \\
\text { Male }\end{array}$ & A1 & A1 & A1 & A1 & A2 & A1 & A1 \\
$\begin{array}{c}\text { Private } \\
\text { Female }\end{array}$ & A1 & A2 & A1 & A1 & B1 & A1 & A1 \\
\hline
\end{tabular}

\section{Conclusions}

The aim of this study was to find and explore the language learning gaps of intermediate level students (Grade 12) in government and private sector schools in the Bahawalpur district of Pakistan. Even after completing their education, a significant number of students face problems in successful and confident communication in formal and informal situations. Most of the time, students obtain good marks in their school English subjects, but they fail to develop communicative competence and language proficiency skills as set out by the CEFR. With this observation in mind, this researchers carried out this study to identify what students are being taught in schools. The results obtained from the participants after the careful, systematic and exhaustive analysis of the data reflect a vivid but challenging situation of our educational system. There were huge gaps found between the existing ESL proficiency skills of learners and the required minimum standards offered by independent assessment frameworks. With a minimum variation between the students from government and private sector schools, and male and female students, the majority of the learners did not meet the basic standards for different language skills assessed: reading, writing, listening, speaking, 
vocabulary, grammar and sociolinguistic appropriateness. The English language skills being taught at intermediate level (Grade 12), while seeming to fulfill schools' assessment needs, fail to fulfill learners' communication needs in English. This leads to us making strong recommendations to revise the pedagogical plans as well as assessment techniques in Pakistani English classrooms. The existing learning gaps of ESL learners can be covered by introducing a communicative English language syllabi, as well as innovative teaching techniques with functional evaluation criteria.

\section{References}

Francis, D., Rivera, M., Lesaux, N., Kieffer, M., \& Rivera, H. (2006). Practical guidelines for the education of English language learners: Research-based recommendations for instruction and academic interventions. Portsmouth, NH: RMC Research Corporation, Center on Instruction.

Hirsch, D. (2007). Experiences of poverty and educational disadvantages. Joseph Rowntree Foundation.

NEP (2009). National standards of educational reforms. Government of Pakistan.

Taherdoost, H. (2016). Sampling methods in research methodology: How to choose a sampling technique for research. International Journal of Academic Research in Management 5, 18-27. DOI: https://doi.org/10.2139/ssrn.3205035.

\section{Appendix 1: Checklist}

Read the statements and decide if what is described is very easy (1), rather easy (2), rather difficult (3) or very difficult (4) for you to do. Circle what fits best!

\begin{tabular}{|c|c|c|c|c|c|}
\hline No & Statement & $\begin{array}{l}\text { Very } \\
\text { Easy }\end{array}$ & $\begin{array}{l}\text { Rather } \\
\text { Easy }\end{array}$ & $\begin{array}{l}\text { Rather } \\
\text { Difficult }\end{array}$ & $\begin{array}{c}\text { Very } \\
\text { Difficult }\end{array}$ \\
\hline 1 & How did you find this test? & & & & \\
\hline 2 & $\begin{array}{l}\text { I can understand instructions and questions } \\
\text { or requests in everyday English. }\end{array}$ & & & & \\
\hline 3 & $\begin{array}{l}\text { I can understand the main aspects of } \\
\text { stories and short stories, if they deal with } \\
\text { themes which are familiar to me from } \\
\text { school and free time }\end{array}$ & & & & \\
\hline 4 & $\begin{array}{l}\text { I can get information which is important to } \\
\text { me from radio and TV programs, if they } \\
\text { deal with familiar topics. }\end{array}$ & & & & \\
\hline 5 & $\begin{array}{l}\text { I can understand radio and TV programs, } \\
\text { CDs or cassette programs even if I do not }\end{array}$ & & & & \\
\hline
\end{tabular}




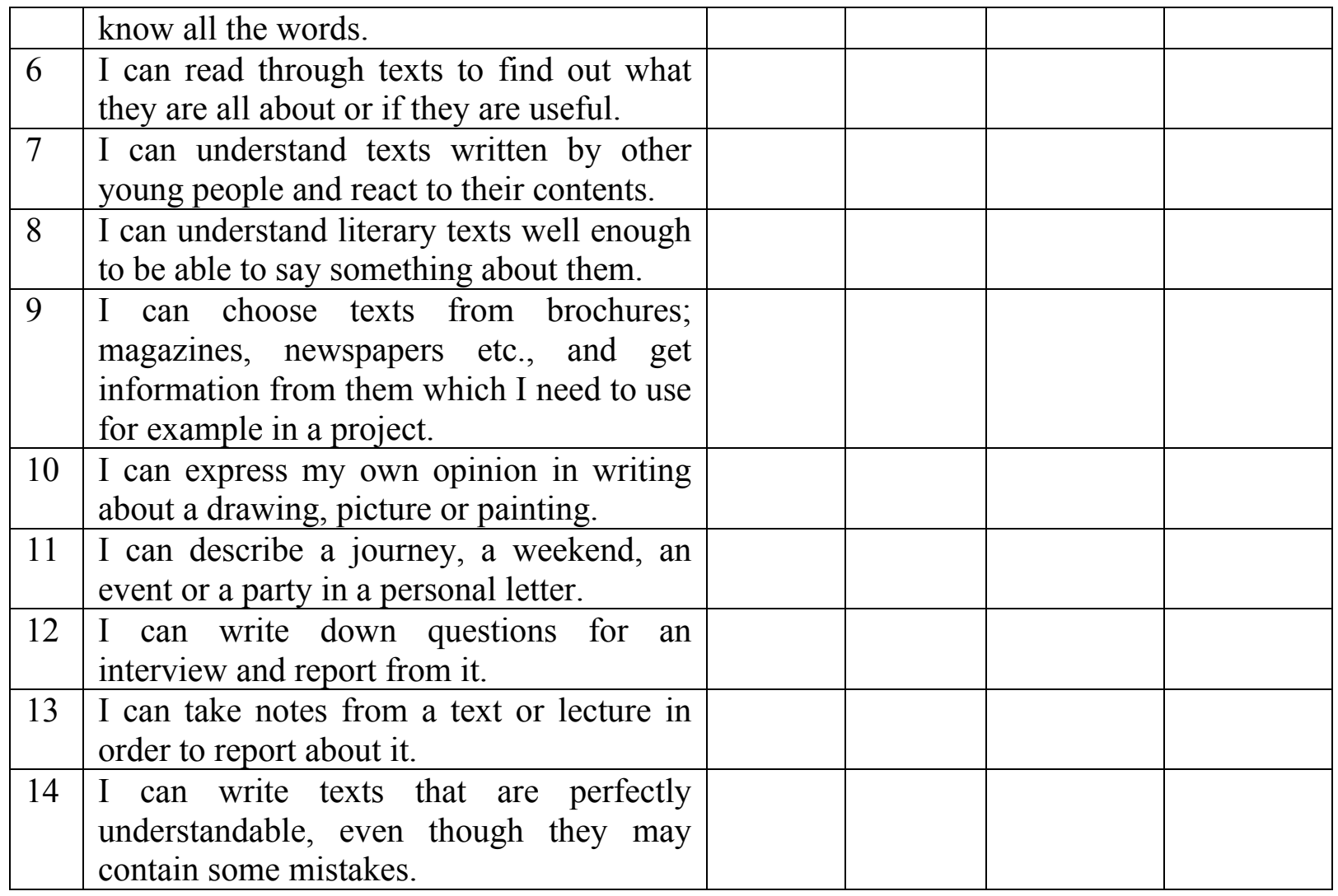

\section{Appendix 2: Questionnaire}

Dear Student,

I am working on research topic "Identifying Language Learning Gaps of ESL students at secondary level". In order to pursue my research venture successfully, I am in need of your valuable time and information based upon your knowledge and experience. I assure the results will be kept confidential and anonymous.

Name:

Gender: $\quad$ Male / Female

Institution: Govt. / Private

Residence: Urban / Rural

\begin{tabular}{|l|l|l|l|l|l|}
\hline Skill & Level & \multicolumn{1}{|c|}{ Statement } & $\begin{array}{c}\text { Always } \\
\text { true of } \\
\text { me }\end{array}$ & $\begin{array}{c}\text { Somewhat } \\
\text { true of me }\end{array}$ & $\begin{array}{c}\text { Never } \\
\text { true of } \\
\text { me }\end{array}$ \\
\hline \multirow{3}{*}{} & A1 & $\begin{array}{l}\text { I can understand short, simple } \\
\text { messages, e.g. on postcards. }\end{array}$ & & \\
\cline { 2 - 6 } & A2 & $\begin{array}{l}\text { I can understand everyday signs and } \\
\text { notices in public places, such as } \\
\text { streets, restaurants, railway stations } \\
\text { and in workplaces. }\end{array}$ & & \\
\cline { 2 - 6 } & B1 & I can search one long or several short & & & \\
\hline
\end{tabular}




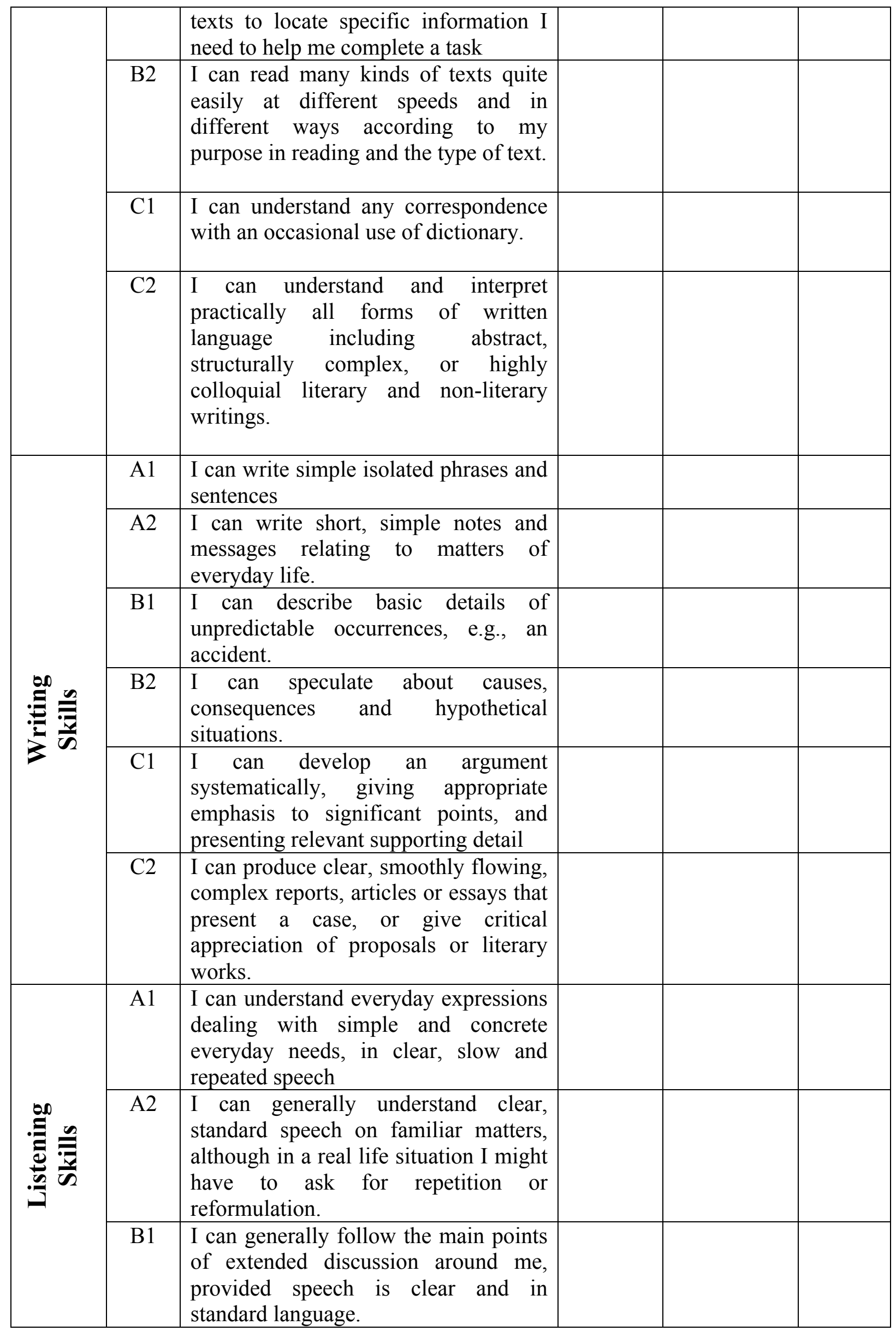




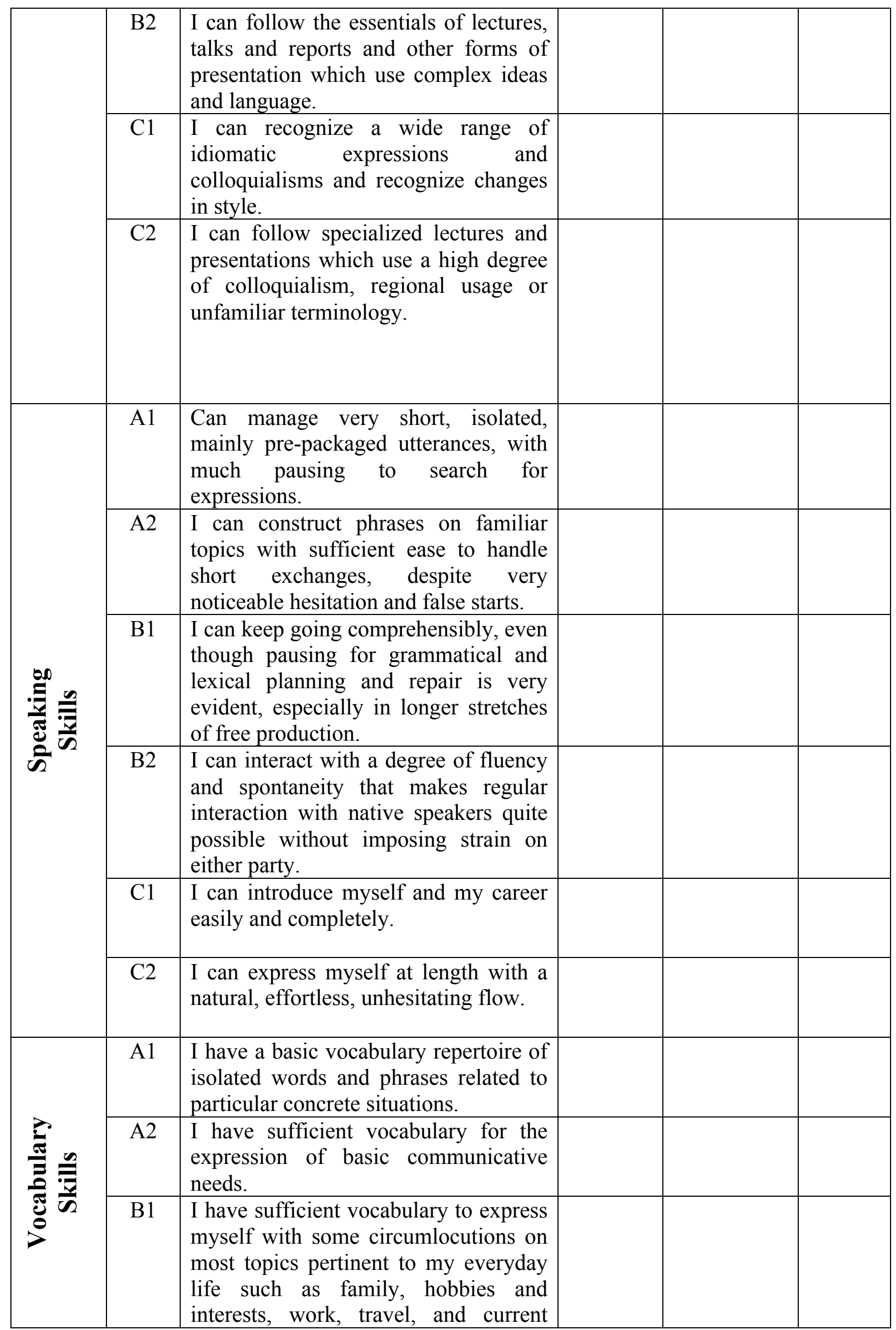




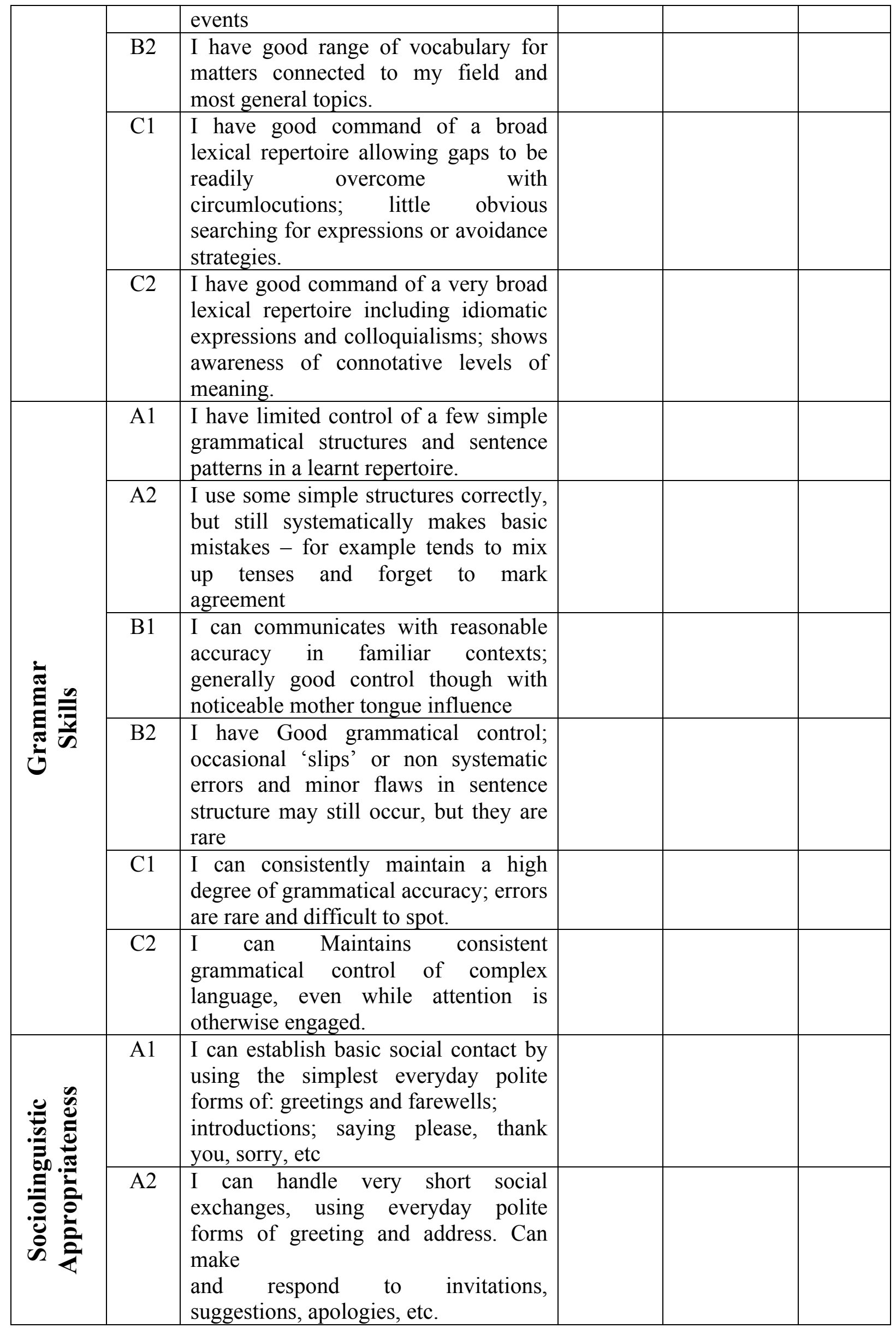




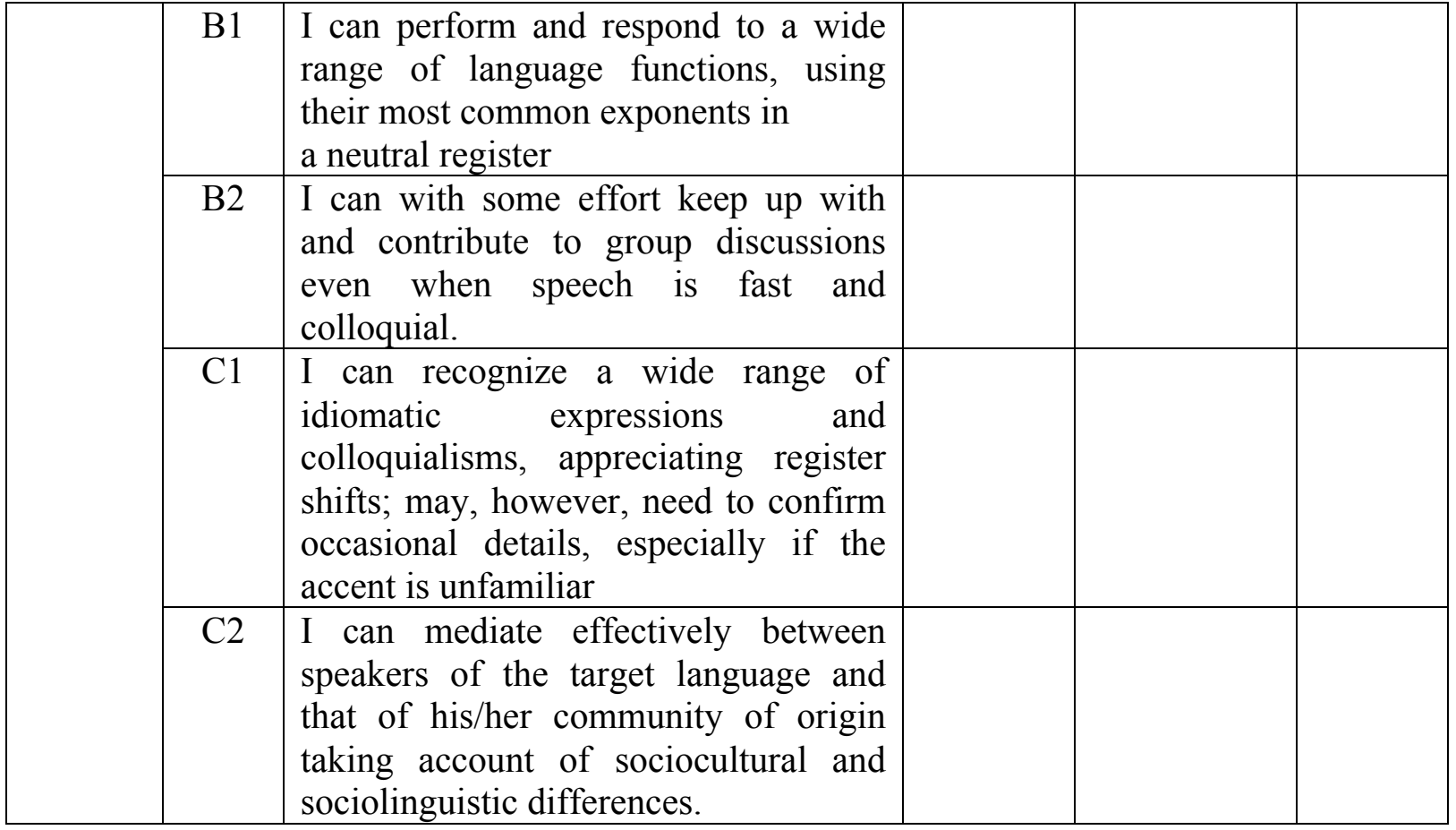

\section{Authors' information}

Muhammad Arfan Lodhi is a PhD in English Linguistics. He passed his $\mathrm{PhD}$ dissertation in 2017. He has been connected with the fields of English teaching and teacher training for the last 13 years. His areas of interest are syntax, discourse analysis, teacher education, and materials development.

E-mail: samaritan_as@hotmail.com

Amber Akash is a M.Phil scholar in English Linguistics at NCBA\&E University, Lahore. She is currently working in the education department of the early childhood education network.

E-mail: amberakash1980@hotmail.com

To cite this article:

Lodhi, M. A. \& Akash, A. (2019). Identifying language learning gaps of ESL students at intermediate level in Pakistani colleges. Bellaterra Journal of Teaching \& Learning Language \& Literature, 12(1), 44-64. DOI: https://doi.org/10.5565/rev/jt13.783

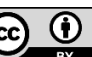

